\title{
Tagore’s Poetry—Universal Psychospirituality
}

\author{
Tinni Dutta \\ Asutosh College, Kolkata, India
}

\begin{abstract}
Life was full of pathos and stress to Tagore. Tagore remains preoccupied with the irrecoverable losses but finally has felt-soothing thought spring out of human suffering. He did not grieve rather find strengths in what remains behind. The poet has gained abundant pleasure from the natural world knowing nature never did betray. Psychodynamically by identifying and introjecting mother figure he felt the most enduring human passion - “Serenity”. Thus despite the barriers of time and space, nation and race, Tagore as an affectionate father may embrace fellow human beings most endearingly. The principal objective is to probe Tagore's psychodynamics and creative processes. Dynamic analysis was done by following the methods of Freud, Jung, and Kris. Findings highlighted that Tagore was a man who could be rightly called "Lord of speech with mind for all”.
\end{abstract}

Keywords: Psychodynamics, Tagore, creative processes

\section{Introduction and Literature Survey}

Tagore viewed consciousness which include psychological as well as metaphysical notions. According to Tagore, consciousness has its objective and subjective aspects. Objective aspects refer to knowledge, information, and perception of events. Subjective aspect means phenomenal experience. Paradoxical awareness and subliminal perception-Tagore experienced it and these are reflected in his songs and poetry. Paradoxical awareness is a kind of knowing without knowing and subliminal perception means that human beings might be influenced by objects and events of which they have no subjective awareness.

Tagore's experience of spirituality is a function of the soul in which all knowledge is rooted. The soul is the greatest of all cosmic miracles. It is the condition sine qua non of the world as an object. Upanishadic singular consciousness is echoed in Tagore's poetry. We can utter-“The colour of my consciousness turned emerald to green, ruby turned crimson. I looked up to the sky, the light was lit... Across to the east and west. I looked at the roses, said 'beautiful', they became beautiful” (Tagore, 1936).

According to Sanyal (2012) there is increasing evidence that many people who experience extra ordinary states of consciousness accompanied by various emotional, perceptual, and psychosomatic experiences are actually undergoing an evolutionary crisis. She has also stated Grof used the term "spiritual emergence" and "spiritual emergency" to refer to this profound personal transformation.

\section{Methodology}

Dynamic analysis: The transcendental element in Tagore's treatment of bereavement and loss, his ability to pass from grief to spiritual realization makes the reader's mind puzzled and is quizzical. This is an analysis of way he does this and it reveals beautifully in Tagore's Gitanjali (Song offerings).

Tinni Dutta, Ph.D., Asutosh College, University of Calcutta. 
A rational study of the psychology behind the profundity of the literary wealth of Gitanjali is rewarding and fruitful. The philosophical content is wonderful in its range and scope. The universal appeal of the thought-content touches the chord of every subject under sun.

Poems are analyzed in the light of Psycho dynamic School. Such personal transformation is evidenced in Tagore's poetry. In Gitanjali, Tagore's quest for spirituality is marked by his eternal pursuit of realizing his essential unity with the infinite. According to him "Consciousness is the light by the help of which we travel along our path of life" and "Spiritual life is the emancipation of consciousness" (Roy, 2010, p. 308). "When the veil is removed, we not only see the fleeting forms of the world but also come close to its eternal being which is ineffable beauty" (Roy, 2010, p. 308). Union with higher power is revealed in the following poetry of Tagore:

The time that my journey takes is long and the way of it long. I came out on the chariot of the first gleam of light and pursued my voyage through the wilderness of the worlds leaving my track on many a star and planet. (Tagore 1912-Song No 12-Song offerings)

When the heart is hard and parched up, come upon me with a shower of mercy. When grace is lost from life, come with a burst of song. (Tagore 1912—Song No 39—Song offerings)

Have you not heard his silent steps? He comes, comes ever comes. (Tagore 1912—Song No 45—Song offerings)

I know not from what distant time thou art ever coming nearer to meet me. Thy sun and stars can never keep the hidden from me for aye. (Tagore 1912—Song No 46—Song offerings)

A feeling of eternity and oneness with the universe resounds in the hearts of the romantic poets. This encompasses a "peculiar feeling”, "a sense of eternity", "a feeling as of something limitless, unbounded as if it were oceanic”. Freud understands this oceanic feeling as being a feeling of an indissoluble bond of being one with the external world.

Feeling of gratitude with higher power is also pronounced in Tagore's poetry.

Thou hast made me endless, such is thy pleasure. This frail vessel thou emptiest again and again, and fillest it ever with fresh life. (Tagore, 1912—Song No 1-Song offerings)

This is my prayer to thee, my lord-strike strike at the root of penury in my heart. Give me the strength lightly to bear my joys and sorrows... Give me the strength to make my love fruitful and service. (Tagore 1912—Song No 36—Song offerings)

Is it beyond thee to be glad with the gladness of this rhythm? To be tossed and lost and broken in the whirl of this fearful joy? (Tagore 1912-Song No 70-Song offerings)

My desires are many and my cry is pitiful, but didst thou save me by hard refusals; and this strong mercy has been wrought into my life through and through. (Tagore 1912—Song No 14—Song offerings)

Tagore has shown a process of reforming the psyche as a form of self healing.

Here we can quote Sanyal (2012) again "It indicates a spontaneous attempt of the psyche to heal itself of unbearable conflicts by melting down and then being reborn in a more adaptive form".

The mastery and specialty of Tagore lie in that by his extraordinary creation he could convey his unique experiences and impart sense of spirituality amongst his readers. Tagore has written:

From infancy I had been seeing only with my eyes, now I began to see with the whole of my consciousness... I sensed the fathomless depths of the eternal well of joy, from which numberless sprays of laughter fly and scatter throughout the world. (Tagore, 1917, p. 156) 
Life was full of pathos and stress to Tagore. Tagore remains preoccupied with the irrecoverable losses but finally has felt-soothing thought spring out of human suffering. He did not grieve rather find strengths in what remains behind. The poet has gained abundant pleasure from the natural world knowing nature never did betray. Psychodynamically by identifying and introjecting mother figure he felt the most enduring human passion - "Serenity". Thus despite the barriers of time and space, nation and race, Tagore as an affectionate father may embrace fellow human beings most endearingly.

\section{Conclusion}

The sense of oceanic wonder, the most sublimated expression of the self transcending emotions is the root of Tagore's creation. The emotions expressed in such creations reveal the universal characteristics of psychospirituality. According to Freud (1917), the artist loses in his dreams what is personal about him and makes it possible for others to save enjoyment, to derive consolation and alleviation from their own sources of pleasures in their unconscious'. Tagore has dedicated his extraordinary vision to Lord of Life and we can conclude by uttering these following lines_- "In one salutation to thee, my God, let all my senses spread out and touch this world at thy feet”.

\section{References}

Freud, S. (1917). Introductory lectures on psychoanalysis. London: Hograth Press.

Roy, K. (2010).Rabindranath Tagore's quest for spirituality "Spirituality and science of consciousness". Kolkata: The Ramkrishna Mission Institute of Clcutta.

Sanyal, N. (2012). The petals of "Forgiveness" in the platter of "Metanoia”. Bulletin of the Ramkrishna Mission Institute of Culture, Golpark, No. 5.

Tagore, R. (1917). Reminiscences. New Delhi: Macmillan.

Tagore, R. (1965). Gitanjali. London: Macmillan Limited.

Tagore, S. (1936). I. Rabindra Rachanabali transcreation. 